\title{
Corporate Social Responsibility in the Russian Federation:
}

\section{A Contextualized Approach}

Abstract Corporate social responsibility (CSR) has emerged as a concept for business from within developed, Western economies. Such economies are underpinned by functioning institutions, where compliance with regulation is assumed. Recently, however, the ability of this traditional CSR approach to take account of the different economic and institutional arrangements found in non-Western contexts has been challenged. It has been argued that CSR research needs to be more contextualized, and that the Western interpretation and assumptions about what CSR is and how it is enacted needs to be broadened and challenged to take account of different stages of economic development. With this argument in mind, this article presents a contextualized critique of CSR undertaken in the Russian Federation. Based on a qualitative study involving managers within privatized Russian firms, this article explores the type, nature, and scope of CSR undertaken and attendant motivation of firms to engage in CSR practice. By taking account of the historical and cultural antecedents of both the Soviet Union and the post-Soviet transition period, the author reveals that while the market is driving conventional forms of CSR within some Russian firms, the historical legacy of both the Soviet Union and more recent political developments have a stronger influence on the type and nature of CSR undertaken. These findings challenge the assumptions about both the voluntary nature of CSR and the pre-requisites needed for CSR to take place.

\section{Keywords}

Corporate social responsibility, Russian Federation, voluntary, coerced 
Traditionally, CSR has been based on the assumption that firms will voluntarily (Carroll \& Shabana, 2010; Crouch, 2006; Dahlsrud, 2008) engage in activity to address perceived responsibilities outside the firm's legal and economic obligations; otherwise known as going "beyond compliance" (Davis, 1973). Recently, however, a number of scholars (Argandoña \& Hoivik, 2009; Devinney, 2009; Dobers, 2009; Dobers \& Halme, 2009; Halme, Roome, \& Dobers, 2009; Preuss \& Barkemeyer, 2011) have challenged the capacity of this traditional CSR approach to take account of the different economic and institutional arrangements found within developing, emerging and transition environments. Halme et al. (2009, p. 2) assert that corporate responsibility is determined by "the institutional, legal and cultural setting within which business is practiced." Preuss \& Barkemeyer (2011) echo Halme et al. (2009) by asserting that, despite globalizing pressure for convergence within managerial practice, the national context of institutions, legal framework, and cultural antecedents can and does influence the way in which CSR is practiced. Consequently, the context within which business activity is enacted can determine the scope and nature of CSR practiced, leading to continued divergence across nation states. Thus in countries where institutions are weak, where property rights are applied inconsistently, and/or the enforcement of law is arbitrary, CSR may not be absent, but instead given a different "twist" (Dobers \& Halme, 2009, p. 242).

Echoing this different "twist" (Dobers \& Halme, 2009, p. 242), in a comparative study of firms in Turkey, Ethiopia, and Singapore, Robertson (2009) concluded that CSR is a concept "in flux" and will take different forms in different countries. Barkemeyer (2009), in a study of the CSR aspect of the UN Global Compact, concluded that Western approaches to CSR have limited use in non-Western context, particularly 
in transition countries. Jamali \& Mirshak (2007) note that where tax evasion, corruption and fraud are commonplace, a responsible company is one that complies with the law and codes of conduct, rather than going beyond it. Collectively these and other scholars (Baughn, Bodie, \& McIntosh (2007); Blasco \& Zølner, 2010; Chapple \& Moon, 2005) argue that CSR research needs to be more contextualized, and that traditional assumptions about what CSR is and how it is enacted need to be broadened and challenged to take account of different stages of economic development. Without appreciating the institutional, legal and cultural context (Halme et al., 2009), understandings regarding the type, nature and scope of the CSR being undertaken in non-Western settings are likely to be misinterpreted or lost.

As a result, interpreting CSR in non-Western locations has begun to gain some traction within the literature. However, despite increasing research on CSR in emerging and developing countries (Arli \& Lasmono, 2010; Arya \& Zhang, 2009; Muller \& Kolk 2010; Robertson, 2009; Visser, 2005), work examining CSR in transition countries outside of China (Darigan \& Post, 2009; Li \& Zhang, 2010; Lin, 2010; Xu \& Yang, 2010) has been lacking. To date, this literature consists only of a small number of individual studies that draw very different and contradictory conclusions.

McCarthy \& Puffer (2008) for example, examine firm behavior in Russia using corporate governance as a substitute for CSR. Ray (2008) and Zueva-Owens and Fairbrass (2010) instead present single case studies. Ray (2008) describes Shell's operations in the Sakhalin region, depicting a multinational company "doing" CSR in Russia, whilst offering no reference to the activity of indigenous firms. Zueva-Owens \& Fairbrass (2010) present a case study of a hydro-electric power station in Siberia, examining the influence or lack thereof, of civil society shaping CSR practice in Russia. Conversely, Kuznetsov, Kuznetsova \& Warren (2009) use a self-reporting quantitative 
survey of Russian firms to conclude that Russian managers do not view CSR as a legitimate activity for business, whilst Preuss \& Barkemeyer (2011) use company reports to indicate that a significant proportion of large Russian firms do include CSR information within their external reporting, although often only in the English language. With only five studies employing differing methodological approaches, conclusions about the scope, nature and type of CSR practiced within individual Russian firms are difficult to draw. Similarly, studies from other eastern European countries add little clarity. Wildowicz-Giegiel (2010), in a study of Polish firms, found that CSR was limited to ad hoc philanthropy and charitable donations. Stoian \& Zhania (2009) in direct contrast to the findings of Zueva-Owens \& Fairbrass (2010) identified civil society as a key driver of CSR activity within Romanian firms. Koleva, RodetKroichvili, David \& Marasova (2010), on the other hand, in a comparative study examining four central and eastern European countries, found that the legacy of the Soviet Union was the key driver of CSR.

Thus to add clarity to the extant literature on CSR and to establish the extent to which CSR in the Russian Federation is contextualized, the author operationalizes qualitative data collected from firms in three industrial regions in the Russian Federation. The rest of the article is therefore organized into five sections as follows. First, the author examines the development and scope of CSR theory. The author then presents the Russian context within which she hopes to shed light. An overview of the methodology employed is reviewed before presenting the findings in a separate section. Conclusions are then drawn.

\section{The Development and Scope of CSR}


Carroll (1991), in his now seminal work, viewed the obligations of the firm as a hierarchy ascending through: economic - making a profit for the shareholders; legal obeying the law; ethical - doing no harm; and finally philanthropic - making a contribution to society. Within this framework, economic and legal responsibilities were viewed as mandatory; ethical responsibility was considered socially necessary; and philanthropic responsibility was considered socially desirable. Failure by the firm to engage with their total responsibilities risked the loss of legitimacy, resulting in poor commercial outcomes.

More recently the issue of "legitimacy" has been folded into the reformulation of CSR as Corporate Citizenship (CC) (Wood \& Logsdon, 2001). Rather than having discrete responsibilities towards the wider citizenry, the firm as a legal entity is itself viewed as a citizen, and thus its "obligations" are reconfigured as rights and responsibilities. By acting as a good "corporate citizen", the firm can insure its legitimacy and in turn, its profitability. Establishing an obligation through legitimacy however does not resolve the limits of the firm's social obligations. Nor does it indicate the extent to which firms should sacrifice profitability to ensure that these wider social obligations are met.

Devinney (2009) asserts that the conceptualization of CSR can be viewed as both broad and narrow. A narrow approach assumes that these obligations are limited to those stakeholders who can make a credible claim on them. Proponents of this narrow approach include Lantos (2001) and Windsor (2006) who assert that CSR should only be pursued where it contributes to the strategic goals of the organisation, and thus reject the infusion of a political or social dimension into the scope of the organisation. This instrumental approach or "doing well by doing good" (Vogel, 2005) has led a number of 
scholars to establish a link between corporate, social and financial performance (McWilliams \& Siegel, 2000; Waddock \& Graves, 1997).

Conversely, a broad approach to CSR assumes that the firm should be an instrument of public policy, with obligations that extend beyond its immediate stakeholders. This more normative approach assumes that the firm will engage in CSR irrespective of the cost to the business, because it is 'the right thing to do.' Promoted primarily by Matten \& Crane (2005) and Scherer \& Palazzo (2007), this approach is grounded in the $\mathrm{CC}$ literature which views the firm as a corporate citizen with attendant rights and responsibilities (Wood \& Logsdon, 2001). These scholars increase the level of obligation on the firm with respect to societal engagement. Matten \& Crane (2005) assert that where the state is weak, the firm often inhabits a role more akin to purveyor of citizenship. In many developing countries, multinational firms are often found to be a substitute for the state, supporting services that would traditionally be provided by governments. However, substituting for the state can also create problems with legitimacy. To counter this legitimacy problem, Scherer \& Palazzo (2007) contend that firms should involve a broad range of community stakeholders in CSR decision making, thereby diluting the firm's discretion as to scope and nature of CSR undertaken. Within this broad configuration it is assumed that firms will adopt these wider obligations, not because they are compelled to, or because it makes commercial sense, but because it is "the right thing to do". Taken at its most extreme, this approach alters the remit of the firm from being solely an economic entity to something more akin to the state or policy maker; an approach that Lantos (2001) and Windsor (2006) wholly reject.

In debating the normative or instrumental nature of CSR, however, these scholars ignore why or under what conditions firms are likely to engage in CSR activity. Campbell (2007) and Matten \& Moon (2008) assert that certain prerequisites are 
necessary for CSR activity to take place. These prerequisites essentially mirror the basic tenets of a market-based economy. First, CSR requires a functioning market where firms have "discretion over their responses to market, social and political drivers" (Matten \& Moon, 2008, p. 406). Functioning institutions that administer the market and compensate for market failure are also required, alongside an active civil society able to hold the state to account. In addition, key actors, such as the state, business and government must not be "captured" or able to influence each other to improve their own situation at the expense of the public interest. Such pre-requisites ensure that key "actors operate according to some measure of mutual responsiveness, interdependency, choice, and capacity" (Matten \& Moon, 2008, p. 407). In their absence, opportunities for “irresponsibility” increase.

Looking for CSR in environments where these prerequisites do not hold raises a number of questions however. If legislative compliance has traditionally been viewed as optional, would a socially responsible firm be that which choose to comply with regulation? If civil society does not function then maybe it is difficult for firms to gauge what society wants or demands from its organizations (Scherer \& Palazzo, 2007). If actors are captured, do firms voluntarily engage in CSR? Where more than one of these prerequisites of CSR do not hold, do firms configure their activity as instrumental (Lantos, 2001; Windsor, 2006) or normative (Matten \& Crane, 2005; Scherer \& Palazzo, 2007), or are different interpretations adopted? What do these different interpretations tell us about the nature of CSR in such settings?

Both Halme et al. (2009) and Preuss \& Barkermayer (2011) contend that the national context of institutions, legal framework, and cultural antecedents can and do influence the way in which CSR is practiced. In this article therefore it is necessary to 
appraise the Russian national context with a view to exploring the potential divergence in approach to CSR in this business environment.

\section{The Russian Context}

With the collapse of the Soviet Union, Russia was seen as a tabula rasa on which to build a market-based economy. By the late 1990s, however, with firms operating in an institutional vacuum and supervised by a weak state (Gel'man, 2003), it was clear that this experiment had failed. In its place had emerged a "chaotic" (Lane, 2000) form of capitalism, dominated by corruption and the "unrule" of law (Holmes, 1997). This "chaotic capitalism" was accompanied by "over withdrawal" (Sil \& Chen, 2004) or fragmentation of the state from areas where it has previously been responsible, led to: the displacement of monetary policy by barter surrogates (Woodruff, 1999); devolution of power from the federal center to regional fiefdoms (Stoner-Weiss, 1999); widespread corruption, non-payment of taxes, and organized crime (Holmes, 2008; Yakovlev, 2001); weak institutions (Puffer \& McCarthy, 2011); and the diffusion of "capture” by so-called "oligarchs" over the state (Hellman 1998; Solnick 1999). With the ability to shape regulation to service their own interests and to determine the makeup of regional and federal legislatures (Frye, 2002; Gustafson 2000), these oligarchs were in effect governing the Russian Federation in tandem with ruling elites (Hanson \& Teague, 2005).

With his ascendancy to the presidency in 2000, Vladimir Putin engaged in vigorous attempts to restore the state's capacity, strengthen the rule of law, and open Russia's markets to global trade. In contrast to both the Soviet period, where the economy was closed to global markets, and the El'tsin era, where a lack of functioning institutions discouraged international trade, Putin sought to tighten the regulatory 
framework to promote trade abroad, particularly in extractive and heavy industries. To this end, institutions were strengthened, money surrogates were outlawed, and the fiscal and judicial system overhauled in an attempt to reduce corruption, enforce property rights and increase tax revenues (Abdelal, 2010). Putin also remodeled the state's relationship with the oligarchs, forcing some into exile and others into prison (Puffer \& McCarthy, 2007) and took some strategically important industries - including defense, oil, and gas - back into state ownership (Vahtra, Liuhto, \& Lorentz, 2007). As a result, business-state relations moved first from "state capture" to "elite exchange" in which firms receive favorable treatment in return for providing benefits to state agents (Frye, 2002; Rutland, 2001), and subsequently to business capture (Yakovlev, 2006). Business capture was achieved by creating a milieu of excessive regulation, meaning that ignoring regulatory requirements was no longer an option. However, by multiplying significantly the number of rules and regulations that every Russian firm had to abide by, all firms, no matter how law abiding, risked contravening at least one. Firms were therefore incentivized to acquiesce to the state if they did not want to be in receipt of excessive punishment, effectively giving the state "absolute dominance over business" (Yakovlev, 2006, p. 1054).

The development of "business capture" (Yakovlev, 2006) emerged alongside other measures taken by Putin, and subsequently Dmitri Medvedev, to "manage" Russia's democratic development. Since 2000 Putin has attempted to control the press (Rosefielde \& Hlouskova, 2007) and federal and regional legislatures, with Putin's "United Russia" party now dominating both (Wegren \& Konitzer, 2007). At the same time, Putin also sought to manage or control Russia's civil society development. Already weak at the time that the Soviet Union collapsed, attempts by third sector organizations and NGOs to invigorate Russia's civil sector have been unsuccessful. Thwarted by a 
lack of resources and a 'closed shop' mentality, most NGOs failed to either hold the state to account, or reach out to the wider public. The ability of groups to do so was further diluted by Putin passing a law in 2006 that prohibited domestic NGOs from accessing foreign donor money and introduced complex additional registration requirements for all groups (Kahmi, 2006). Consequently, many NGOs have sacrificed their independence by taking state money to ensure their survival. As a result, the state is now unchallenged in almost all spheres of its activity, leading many to describe Russia as a "managed democracy" (Mandel, 2005; Wegren \& Konitzer, 2007).

Against this background of both corruption and subsequently increased state control, there is evidence that the legacy of the Soviet Union continued to pervade firm activity with respect to their employees and surroundings. During the Soviet period the firm performed a social as well as an economic function, providing individuals not only with guaranteed employment, but also subsidized housing, health clinics, childcare and so on. The paternalistic relationship developed during the Soviet period - between the firm, its workforce and its broader societal setting in the past (Kornai, 1992) - has continued to influence managerial behavior during transition. Although firms engaged in corrupt and sub-optimal behavior during the early 1990s period of transition, (Holmes, 2008; Yakovlev, 2001) managers also demonstrated a reluctance to shed labor, preferring instead to retain their social assets (Carlin et al., 1995) and keep employees on the books as unpaid, and usually underemployed workers, rather than lay them off (Ashwin, 1998).

Thus, what constitutes CSR in a country with a history of non-payment of taxes, wages (Earle, Spice, and Peter, 2010) and corruption (Holmes, 2008), is likely to be different from that where fiscal and regulatory compliance was taken for granted. Similarly, CSR is likely to be enacted in a different way where some of the prerequisites 
of CSR (Matten \& Moon, 2008) are absent. A managed democracy (Wegren \& Konitzer, 2007) and business capture are likely to provide different CSR outcomes to those environments where democratic processes and markets are not subject to state interference and control. Likewise, a managed civil society is unlikely to send clear signals to firms as to the type, nature and scope of CSR demanded by the general population, leaving firms to impose their interpretation of CSR onto local communities. In contrast, Putin's focus on international trade gives Western firms greater access to Russian markets and vice versa. Thus, is it possible for open markets to influence CSR despite an absence of the prescribed pre-requisites? Given these factors in this article, the author seeks answers to the following questions:

- What constitutes CSR in a country where regulatory compliance was once viewed as optional?

- What impact does elite capture and stifled democratic development have on the type of CSR practiced?

- What impact do open markets and globalization have on CSR activity?

- To what extent is Russian CSR contextualized?

Before these questions are examined in detail however, an overview of the research methodology is presented.

\section{Methodology}

This study, using information collected as part of a wider UK Economic and Social Research Council-funded research project, arises from three industrial Krai and Oblasti $^{l}$ in the Russian Federation. The Oblasti of Samara and Volgograd and Stavropol 
Krai were chose for our study because the urban centers of Moscow and St. Petersburg do not always represent the experience of organizations in provincial Russia (Javeline \& Lindemann-Komarova 2010). In addition, as Moscow and St. Petersburg have been subjected to greater forces of economic and social transformation (Mansvelt 2005) than other areas of Russia, it is unlikely that findings in these two cities with regards to CSR and many other business practices would be representative of that found within firms outside of these them. Moreover the majority of Russia's population lives outside of these two cities, and due to the legacy of Soviet central planning, many industrial hubs and centers for manufacturing continue to be located outside of Moscow and St. Petersburg.

All three of the regions chosen for this study have a GRP (gross regional product) per capita within the Russian average (IMF Russia, 2008) and are $80 \%$ or greater ethnic Russian (Federal Statistics Service, 2011). During the Soviet period, Kybyshev Oblast', as it was known until 1990, was a hub for automotive manufacturing. Today, Samara Oblast', located in the Volga region, remains the home to the immense Lada Plant, AvtoVAZ in Tol'yatti, and is also one of the top areas of petroleum by-product and machinery production in Russia. It also three large oil refineries, located in Szyran, Novo-Kuibishevsk and Samara, and a hydro-electric power plant located just outside Tol'yatti on the Volga River. Volgograd Oblast' has an economic profile similar to Samara Oblast'. Its economic activity is concentrated in the region's two largest cities, Volgograd and Volzhskiy. Leading industrial branches include chemical production, metallurgy and oil refining. Volgograd is also home to the largest tractor factory in Russia and a hydro-electric dam on the river Volga. Conversely, Stavropol Krai is a more agrarian based economy with industrial activity being largely based around the two cities of Budennovsk (oil refining) and 
Nevinnomyssk (chemical production). In recent years, the Stavropol Krai's economy has benefitted from increased natural gas extraction and the proceeds of the transportation of natural gas and oil from the Northern Caucasus, Caspian Sea and Central Asian republics, to Russia's only warm water port at nearby Novorossiysk. Thus these three regions are not only representative of provincial Russian cities but also provide the study with a sufficiently similar context to examine contrasts and similarities between the regions, minimizing potential regional factors to act as explanatory influences (Miles \& Huberman 1999)

Huberman \& Miles (1994) assert that an inductive research design is undertaken where the territory under enquiry is "excessively complex" and the intent is exploratory. Given the dynamic nature of Russia's economic and social development and the lack of literature on CSR in Russian firms, an inductive research design was deemed appropriate. In line with an inductive approach, the choice of participants was consciously decided by the researcher because of their relevance to the study and their potential to help develop explanations for the phenomenon under examination (Mason, 1996).

Initially, a "wish list" of firms and interview subjects was compiled through internet searches, using the regional administration websites of each oblast to identify key companies. With the assistance of project partners located in Samara State University, Volgograd State University and Stavropol State Agrarian University, additional firms were located. In total, 43 firms were identified. The focus was placed exclusively on privatized industrial firms, domestically owned, wholly or in part. A wide range of manufacturing processes were also captured amongst those interviewed, including chemical processing, ship building, oil and gas, food processing and metal working. As a result the firms varied in size. 
The majority of interviews were conducted in Russian and were all face-to-face and semi-structured. Theoretical debates within the CSR literature, particularly those pertaining to 'context' (Halme, et al., 2009), and the limited literature examining CSR in both Russia and other transition countries (Koleva et. al., 2010; Kuznetsov et. al., 2009; McCarthy \& Puffer, 2008; Ray, 2008; Stoian \& Zhania, 2009; WildowiczGiegiel, 2010) were used to shape both the base-set of questions and data collection methodology.

The focus of this base-set was not only on the type, nature and scope of CSR activity undertaken within each firm, but also managerial perceptions of what constituted CSR activity, and their motivation for undertaking such activity. This baseset was subsequently refined in the field (Huberman \& Miles, 1994), with questions that were misinterpreted or did not translate well being removed. An exclusive "beyond compliance" (Davis, 1973) definition of CSR was not adopted. Instead managers were allowed to define for themselves what they viewed as CSR activity within their own firm.

The interviews were recorded using either a Dictaphone or in the form of ethnographic notes, where appropriate. Each interview lasted between 30 and 90 minutes and assumed a conversation-like approach, where the base set of questions were used to facilitate discussion alongside additional follow-up questions to probe responses and to add further insight. All of the interviews were then translated and transcribed in situ, calling on the skills of the translator where discrepancies arose. Physical examples of CSR activity, including documentation, CSR policy statements and other activities, were also collected. Collecting this documentary data was done in order to increase the understanding of a firm's CSR approach. The interviews usually involved one senior manager from each organization, though in a small number of 
interviews two participants were involved in the conversation. Participants were varied in age and gender, and in their management positioning within the organization.

Once back in the UK, the 43 interviews were subject to theoretical interpretation, based entirely upon the data collected, but with an appreciation of the context in which participants were speaking. The data were then analyzed, looking for patterns and similarities (Berg, 2007). Patterns and similarities were identified by repeated review and by passing the data to a research fellow who also studied the data to minimize the impact of personal preconceptions (Silverman, 1993). Themes emerged from this review (which are mapped onto the findings section in this paper) revealing different approaches to CSR namely, the influence of open markets, philanthropy, the legacy of Soviet business practices on CSR, and the impact of the post-Soviet political and economic environment on CSR, particularly within the larger firms in this study. The data were then coded according to these emergent themes (Charmaz \& Mitchell, 2001), using color coding. By coding for these themes the influence of the historical antecedents of both the Soviet and transition period on the type, nature and scope of CSR adopted within Russian firms were revealed, alongside the power of the market to influence CSR activity, even when other pre-requisites for CSR are absent. The discussion that follows explores these issues using narratives from these interviews, or ‘illuminating examples’ (de Vaus, 2001, p. 240), to exemplify key points.

In order to ensure that the organizations and the participants remain anonymous, and the data confidential, in the discussion that follows the data is referred to according to the adopted coding system. The firms are referred to according to their assigned pseudonym, which is indicative of the industry they are a part of, such as "Aluminum 1." A full list of the firms, under pseudonyms can be found in Appendix 1 of this article. 


\section{Findings}

Before the detailed qualitative results are presented, it is useful to present an overview of the data. Analysis of the transcripts revealed five distinct types of CSR taking place - these are described in Table 1 below.

Table 1: CSR Types

\begin{tabular}{|l|l|}
\hline \multicolumn{1}{|c|}{ CSR Type } & \multicolumn{1}{c|}{ Descriptor } \\
\hline Market Driven (MD) & $\begin{array}{l}\text { CSR most closely reflecting Western descriptions of CSR; } \\
\text { namely that which was driven by commercial concerns, went } \\
\text { beyond compliance and was undertaken voluntarily }\end{array}$ \\
\hline $\begin{array}{l}\text { Soviet Legacy or } \\
\text { Philanthropic (SP) }\end{array}$ & $\begin{array}{l}\text { CSR informed by the paternalistic or social role played by } \\
\text { firms during the Soviet Union }\end{array}$ \\
\hline $\begin{array}{l}\text { Transition Legacy } \\
\text { (TL) }\end{array}$ & $\begin{array}{l}\text { CSR influenced by the legacy of the El'tsin era where } \\
\text { activities such as paying wages and taxes where optional and } \\
\text { are now viewed as a firm's "social contribution" }\end{array}$ \\
\hline Coerced (C) & $\begin{array}{l}\text { CSR reflecting the "captured" nature of state-business } \\
\text { relations in Russia where firms take on social projects at the } \\
\text { behest of the state. }\end{array}$ \\
\hline No CSR activity (N) & No CSR activity was reported \\
\hline
\end{tabular}

Thirteen firms in this study were engaged in MD CSR, Seventeen firms exhibited SL CSR activities, ten firms reported TL CSR and five firms described "coerced" or C CSR. Finally, seven firms reported no CSR (N) activity at all. Overall fifty two incidents of CSR were reported, with twelve firms reporting engagement in two types of CSR - nine of which reported both MD and SP. A single firm reported three CSR types. All of the SP respondents were the single firm in their town or district. The five firms that reported coerced CSR were the largest by turnover in this study (Appendix 1 details these findings by firm). To explore these findings in more detail, the following section is divided into two parts. The first examines incidents of market-driven CSR, motivated by a business case (Lantos, 2001; Windsor, 2006), namely MD and N. The second examines more "contextualized" (Halme et al., 2009) incidents of CSR influenced by the specific cultural and historical antecedents of both the Soviet and transition period, specifically TL, C and SP. A broader discussion of what this study 
has to contribute to the continuing conceptual development of CSR is then entered into in the conclusions.

\section{Market-Driven CSR}

Firms found to be engaged in CSR activity that could be described as "traditional", voluntary or "beyond compliance" (Davis, 1973) focused exclusively on the adoption of codified CSR policies and/or registration with the international environmental standard ISO14001. In all cases, these activities were adopted to gain access to export markets. Eight of firms in this study reported that they had a formal "social" policy that explicitly committed the firm to going beyond their legal and economic obligations. These policies were often wide ranging, committing firms to a broad spectrum of social and environmental projects, as illustrated by the extracts below from Aluminum 2 and Metal Working 1:

Our corporate social policy is wide-ranging, including education, environmental protection, corporate social responsibility, health and social security - especially concerning families and children - and a sustainable partnership between charities and the business sector. (Aluminum 2, Nevinnomyssk, Stavropol Krai')

Corporate social responsibility is an extremely important part of our wider corporate policy in all questions concerning production, labor safety and also ecology. Within that policy we also play a significant role in funding and supporting social activities in our region, including children's organizations and financing charity work. (Metal Working 1, Volzhski, Volgograd Oblast') 
However, the arising wider social benefits from the adoption of a social policy both for the firm and its local community were not discussed by these managers. Instead, they stressed the arising commercial benefits, particularly as they pertained to overseas customers and contracts. Chemical 4, Natural Resources 1 and Aluminum 3, for example, stressed the link between legitimacy and commercial longevity (Carroll, 1991), citing "reputation", "image" and "legitimacy" (with respect to their customers) as strong motivators for their adoption. Others were more explicit about the direct links between the adoption of a social policy and profit, focusing on the "stimulus" (Cosmetics 2) provided by the market, as illustrated by the following discourse;

You know, to survive today in the modern world, in today's tough market conditions, we cannot survive without having a serious corporate social policy and especially in taking extremely seriously ecological questions. The market is the driver here without doubt, in our shifts towards, in particular, [sic] the ecological modernization across our factory. (Metal Working 1, Volzhski, Volgograd Oblast')

In citing the demands of customers and the need to ensure "stable profits" (Automotive 1) these firms were focused much more on the 'doing well' aspect of CSR than the “doing good" (Vogel, 2005). Adopting a codified social program, or being able to demonstrate social responsibility credentials was viewed as essential not just of the ongoing legitimacy of the firm vis-à-vis its customers, but to gain access to and secure contracts from customers located in developed economies where such things are viewed as standard. This observation was reinforced by further scrutiny revealing that these eight and an additional five firms had also sought ISO14001 certification, again to 
secure access to overseas markets. As dialogue from Cosmetics 2 and Chemical 4 explains:

All of the firm's ecological standards comply with European environmental standards ISO14001. This is extremely important for us; it is an absolute must, a prerequisite for our work today. We must react to the demands of our buyers. Our main buyers are European firms... These global firms demand the highest standards, especially in the area of environmental responsibility and thus, in order to continue working with them, we must comply. (Cosmetics 2, Nevinnomyssk, Stavropol Krai)

Market mechanisms are dictating that we keep up with these changes. Our products need to be 'green' now in the eyes of our customers. (Chemical 4, Volgograd, Volgograd Oblast')

Other firms stressed similar motives, including "competitive advantage" (Aluminum, 1; Chemical 7; Metal Working 1), "economic efficiency" (Chemical 3; Chemical 9) and "access to overseas markets" (Natural Resource 5). Yet none referred directly to any arising environmental or social benefits from ISO14001 certification. ISO14001 also had other limits. Discourse at other firms indicated that the pressure of overseas contracts needed to emanate from the right geographical location. A number stated that while they had obtained the international quality standard ISO9000, ISO14001 certification was not necessary because their customers, predominantly from the former Soviet Union, did not require it. Managers at Tractor 1 explained: 
For us, the ISO 9000 system is fine and works well. For our clients in Russia, Ukraine, Belarus and Kazakhstan, this is the most important thing. They are not so worried about ISO14001. (Tractor 1, Volgograd, Volgograd Oblast')

Others stated that ISO14001 was "too expensive" (Chemical 1) "difficult to justify" (Pipe 1) or like Tractor 1 that it was not "demanded by their customers" (Ceramics 1). Collectively this discourse indicates that while some market driven, "voluntary" or "beyond compliance" activity is being undertaken, its scope is very limited. In adopting a "profit is paramount" (Chemical 4) approach, the focus of this CSR is extremely narrow (Devinney, 2009). Where CSR can assist in extending the commercial life of the firm, it was embraced, be that through codified policies or adherence to international standards. Where it did not it was rejected, as illustrated by managers at Pipe 1 when discussing environmental protection and pollution control:

Our owners think that taking the environment seriously involves a lot of money, which they consider simply as a waste of money. They follow a clear logic. Why bother doing something which is expensive for the firm if it is not compulsory? (Pipe 1, Volgograd, Volgograd Oblast')

By emphasizing the commercial benefits of this market driven CSR to the exclusion of any social value, it is unlikely that these firms would have engaged in this CSR activity without the market incentive. This market-driven approach is underscored by the rejection of ISO14001 certification by those with customers inside the former Soviet Union. Despite this "narrow" (Devinney, 2009) focus, however, the influence of overseas customers on the behavior of these firms indicates that market forces can still 
promote "beyond compliance" (Davis, 1973) activity, even when other prerequisites for CSR such as functioning institutions and non-captured actors (Campbell, 2007; Matten \& Moon, 2008) are absent. The presence of other types of CSR, not motivated by market forces, but by the antecedents of both the Soviet Union and the transition period at other firms in this study underlines this finding, indicating that prerequisites may not be necessary for CSR to take place. It is therefore to this "contextualized CSR" that the author now turns.

\section{Contextualized CSR}

Just over half of the firms in this study exhibited CSR activity that was motivated not by commercial reasoning, but by the antecedents of either the Soviet Union or the transition period. Those influenced by the cultural legacy of the Soviet period were strongly aligned to philanthropic activity as the primary vehicle for social intervention, with many stressing the need to ensure the wellbeing of their employees and their families. Those influenced by the transition period cited paying taxes and health and safety - issues that would be viewed as compliance activity in a Western setting - as their contribution to Russian society. Others, particularly larger firms, appeared to be "captured" by regional state actors. As a consequence these firms were compelled or coerced into CSR activity that they would not have otherwise undertaken. These findings are outlined in the analysis below.

\section{Soviet Legacy and Philanthropy}

In this study 17 firms found to be engaged in activity that could be described as charitable or benevolent. Some engaged in this activity on an ad hoc basis: 
We try and sponsor as many local charities as we can. People and organizations in the local population come to us all the time and ask us for some philanthropic support. When we can, we are happy to oblige. (Natural Resources 2, Volgograd, Volgograd Oblast')

While others took a more structured approach:

We have two large programs. The first is "My Birthday". When the child is born on the day of the company's birthday, this child's parents get 10000 rubles, presents, gift certificates during the festive ceremony. The second program is Polyakov Scholarship. It is worth mentioning that the scholarship is for students carrying out the best projects in motor-car construction and mechanical engineering. (Automotive 1, Tol'yatti, Samara Oblast')

Be it ad hoc or structured, the type and nature of the activities undertaken at each of the firms was very similar. Several firms sponsored bursaries, scholarships and educational prizes at schools and Universities in their region. Aluminum 3 for example sponsored students at Samara State Aerospace University, and both Automotive 1 and 3 sponsored students and prizes at Tol'yatti State University, all in their field of expertise. Two firms sponsored orchestras in their relative towns (Automotive 1 and Chemical 8) whilst half sponsored children's projects, ranging from playgrounds to orphanages and health care programs (Chemical 1, 5, 8; Natural Resources 1, 4, 5; Metal Working 1, Aluminum 1). There were potential "commercial" benefits to this type of activity. Sponsoring students at related Universities gave firms direct access to the best and the brightest. Sponsoring orchestras was good public relations. However, when prompted to share 
their motivation for engaging in philanthropic or charitable activity managers, in contrast to those with codified social programs or ISO14001 certification above, failed to stress these benefits. Instead they described philanthropy as a "concept [that] existed in Soviet times" (Aluminum 1), a "traditional" (Aluminum 1) role for the firm to take, and that this philanthropic activity was part of an ongoing "social contract" (Metal Working 1) with the local community that predated the collapse of the Soviet Union. Evidence of this approach to CSR was even more pronounced in so-called 'city forming' enterprises in each region.

Firms around which an entire town, city or district within a city was built were colloquially described during the Soviet period as "city forming" enterprises. These firms would not only provide the lion's share of the employment in that town, city or district, but also administered community facilities (Kornai, 1992). This legacy appeared to be a key driver of CSR within these firms, as the dialogue below illustrates:

Being the city-forming enterprise [sic] and being aware of our continuing social responsibility we continue to voluntarily undertake obligations in the life of Togliatti Urban district population through our Tol'yatti Community Foundation. For example, environmental activities, vocational training support, culture and sport support, helping social groups and public associations and charitable/philanthropic activities. We also maintain a huge medical department, a polyclinic with serves 120,000 people at our own expense. (Automotive 1, Tol'yatti, Samara Oblast')

We still have some "social" roles also which have continued from the Soviet times. In the Soviet times, the factory built several schools and a theatre for its 
workers and also had its own sanatorium near the Black Sea. These facilities were owned by the factory but they were used by the factory's workers and their families. These facilities were either free to use or heavily subsided. Today, the factory tries to do what it can and continues to support these social projects and subsidies for these activities. This is important so that the workers have a feeling of "self-worth" and so that they feel they belong to the wider family which is based around the factory. (Chemical 1, Volzhskii, Volgograd Oblast')

In probing their motivation for continuing this activity, Aluminum 3 stressed that their "responsibility" was to those people who lived and worked in the immediate vicinity of the factory, while Chemical 5 stated:

The Russian Federation has been a Soviet country for about 70 years, with its special ideology and mentality deeply rooted in people's minds. Most of them got used to relying on enterprises forming a company town and budget-forming ones, supporting and backing the whole city... So we do understand that our responsibility is based on some historical traditions and culture in general. That is why we try to maintain or assist with as many of these previous functions as we can. (Chemical 5, Nevinnomyssk, Stavropol Krai)

The discourse in this study illustrates that "city forming" and other privatized enterprises have chosen to continue to occupy a role that previously was part of their mandate as a Soviet enterprise. Previously, the structures of central planning compelled such firms to be both economic and social providers within their local communities. Social benefits such as housing, kindergartens, health centers, social clubs, cheap 
holidays, and in some cases access to luxury goods such as motor vehicles, were both provided and administered by the organization but were also used as benefits to incentivize the workforce. Clarke et al., (1994) even go as so far as to state that the purveying of these social assets was at the foundation of the Soviet production system. Rather than monetary reward for labor output, this form of 'embedded' (Clarke et al., 1994, p.186) paternalism was both expected by the workforce and used to maintain production targets, thus keeping the factory doors open.

In the present one can see the continued influence of these Soviet antecedents within Russian firms as they express a continuing paternalistic approach to the organization's role. The sense of "ought" or normative compulsion to their continuation of this activity indicates that these firms do not view CSR as something that was imported into the Russian Federation. Instead it was a "traditional" approach to philanthropic activity; the way things have always been done. Yet this activity was also more akin to "purveying" (Matten \& Crane, 2005) social benefits onto their immediate surroundings, rather than engaging local communities to influence the type and nature of the activities undertaken. There was no evidence from the interview discourse that firms actively engaged or collaborated with community groups or NGOs in the decision making process with regards to this philanthropic activity (Scherer \& Palazzo, 2007). This lack of NGO interaction is not surprising as during the Soviet period firms engaged or purveyed a social function without any reference to community preferences. The data clearly indicate both that larger or "city forming" firms undertook philanthropic activity despite an absence of pre-requisites for CSR. In addition, it was also clear that these firms did not view CSR as a Western or imported construct. Rather, it was a continuation of activity undertaken under central planning. 


\section{Transition Legacy and Coercion}

In contrast to that presented above, the economic and political precursors of the transition period appeared to influence the scope, nature and type of CSR undertaken at fifteen firms in this study. Ten firms cited activity which in a Western context would be viewed as mandatory and thus not CSR, such as paying taxes and ensuring the health and safety of their workers, whilst others reflected the captured nature of business-state relations in Russia at the current time. Yet five firms reported that the state had "coerced" them into engaging in social projects that would have normally outside of their purview, reflecting the "captured" nature of business elites currently in Russia.

Jamali \& Mirshak (2007) note that where tax evasion, corruption and fraud are commonplace, a responsible company is one that complies with the law and codes of conduct, rather than going beyond them. Against the background of corruption, lack of regulatory enforcement and tax fraud that dominated the early part of the transition process (Earle et al., 2010; Holmes, 2008), it is not surprising that some firms asserted their social responsibility through regulatory compliance, as illustrated by the following discourse:

We pay taxes every year and I employ over one hundred people. I see this as playing my role in the development of Stavropol. (Construction 1, Stavropol, Stavropol Krai)

We provided for the welfare of a large number of people by paying large amounts into the city through taxation every year. This is our social contribution. (Chemical 1, Samara, Samara Oblast') 
Yes, of course, "social" questions are very important for our factory. We understand that we have a responsibility towards our personnel. We aid our workforce as we can. We guarantee that we will provide them with a safe and healthy environment in which they can work. (Asbestos 1, Volzhskii, Volgograd Oblast)

Other participants, in line with Construction 1 and Chemical 1, asserted that paying taxes was "their contribution" (Lime Processing 1) and that, as they were on one of the 'biggest tax payers in the city', this contribution to society was "enough" (Chemical 8). Others, like Asbestos 1, focused on the provision of health and safety as their attempt to address social issues. Automobile 3 stated that their priority was to "protect" the health of their workers, while others had introduced a system of "labor protection" (Chemical 1, 4; Food Processing 2) to ensure worker safety.

If a traditional approach to CSR is taken, then these responses do not represent evidence of CSR. Paying taxes is mandated by the state, providing employment is a necessary function of business and ensuring employee safety is now accepted as a standard activity for firms in a Western context, with employee protection etc., being mandated by law. The application of the historical and cultural antecedents of Russia's transition however contextualizes CSR (Halme et al., 2009) in this setting. Asking Russian managers what they view as CSR or as their contribution to their local community did not necessarily evoke a textbook response. During the early 1990s firms had the choice of whether or not to pay taxes and wages. Many chose not to, with little or no penalty (Holmes, 2008). When asked what contribution firms made to their local community, firms in this study alluded to activities that they previously viewed as optional, but now feel are necessary or at least unavoidable. 
However, the political and economic antecedents of transition had other impacts on CSR. The captured nature of business-state relations in Russia (Frye, 2002; Yakovlev, 2006) had also led to firms being coerced into CSR projects that were not of their choosing. Where the state was unable to provide particular "social" assets, it turned to the largest and/or most profitable firms in their location to provide it for them, as indicated by the following discourse:

You know, sometimes the authorities set up social projects such as building a new sports center or nursery and then the authorities seek to attract "sponsors" for the financing of these projects if their own finances fall short. Of course, they turn to large, local companies, like our factory in the first instance. (Chemical 2, Volzhski, Volgograd Oblast')

The city's sports stadium was owned and financed by another firm in this region, for the people of Nevinnomyssk. A few years ago this firm had problems and needed to sell it... The authorities therefore "asked" our factory to buy the stadium and maintain it for the city's sporting events. (Cosmetics 2, Nevinnomyssk, Stavropol Krai)

This discourse illustrates not only the nature of these coerced projects but also the scale. Chemical 2, 3 and Metal Working 1 were assisting with the construction of new apartment blocks and health facilities. In Samara Oblast', Ceramics 1 had reconstructed and was maintaining the botanical gardens, supplying free labor and all the materials. In Volgograd Oblast', Natural Resources 1 was providing the fuel and repairs at the "Mamayev Kurgan" monument to the Great Patriotic War on the banks of 
the Volga. Firms acquiesced to these (in most cases very large) demands because of the potential benefits it could bring in terms of a better working relationship with the state; "of course, we are not obliged by law to participate in these projects but we need to keep good relations with the local powers that be", (Chemical 2; Cosmetics 2), to "maintain legitimacy" (Chemical 3) or to "secure the future state support" (Chemical 3). These examples, and discourse at other firms, illustrate that if firms refused an approach by the state to provide assistance, they risked the weight of "excessive regulation" (Yakovlev, 2006) as a result. Consequently, firms had little choice but to comply if they were to retain a working relationship with the state. In probing their attitudes towards this matter, firms exhibited a resigned acceptance, as captured succinctly by Metal Working 1:

This is how things work here now. This is the modern form of corporate social responsibility. (Metal Working 1, Volzhski, Volgograd Oblast')

Traditional approaches to CSR assume that - whether motivated by an instrumental or normative bias - it is entered into voluntarily. Yet as these data in a different context illustrate, CSR may not always be voluntary. Russian firms that are "coerced" into CSR projects substitute for the state (Matten \& Crane, 2005) but this coercion can still result in the firm making a significant contribution to its wider community. These findings, along with those vis-a-vis taxation and employment above, illustrate that CSR in different contexts can have a different "twist" (Dobers \& Halme, 2009). Where traditional definitions are set aside, different types of CSR are revealed. The concluding section below explores the implications of these and the other findings in this article. 


\section{Conclusions}

Before discussing the conclusions arising from this study, it is necessary to acknowledge its limitations. The study presents findings from privatized firms from three provincial, largely industrial regions of the Russian Federation. Care must therefore be taken in extending the conclusions drawn here to more rural Oblasti or the autonomous republics situated within the Russian Federation's borders. In addition, this article focused exclusively on privatized firms. Firms that pre-date the collapse of the Soviet Union are more likely to exhibit characteristics, or the cultural legacy, of central planning. A study that focused on private firms or a mix of private and privatized may not have found the Soviet legacy to be so influential, and thus may be less likely to assert the paternalistic role of the enterprise in responding to questions about CSR. Additionally, interpretations or the influence of cultural factors on CSR prior the Soviet period are not explored in this study. The immediate post-revolutionary period was dominated by mass industrialization from what was previously a largely feudal society. As a result, few, if any firms remain from the pre-Revolutionary period. Thus this research focuses the impact of this mass industrialization and associated central planning alongside the economic turmoil linked with transitioning from this economic approach. These factors notwithstanding, the findings do give an insight into the contextualized nature of CSR conducted within privatized firms in industrial locations within provincial Russia, indicating that while traditional, "beyond compliance" CSR is taking place, CSR influenced by the cultural and economic antecedents of both the Soviet Union and the transition period is also commonplace. These findings have a number of implications for the extant literature on CSR in transition and challenge many of the assumptions within the current CSR theory, as explored below. 
First, there are both similarities and contradictions when these findings are compared to those within the limited literature on CSR in the Russian Federation and other former Eastern Bloc countries. Commensurate with findings in this study, Koleva et al. (2010) also found that the legacy of the Soviet Union was the key driver of CSR within privatized firms whilst Wildowicz-Giegiel (2010) found that CSR was limited to philanthropy and charitable donations in Polish firms. Conversely, this study found little evidence to support Kuznetsov et al.'s (2009) assertion that Russian managers did not view CSR as a legitimate activity for business. Echoing Preuss \& Barkermayer's (2011) findings, even if a strict 'beyond compliance' definition is taken, around a third of the firms in this study were engaged in CSR activity for commercial benefit. Only seven out of the 43 firms in this study failed to report any CSR. Also, contrary to Stoian \& Zhania (2009) this study found no link between civil society activity and CSR within individual firms. Instead, in line with the findings of Zueva-Owens and Fairbrass (2010), firms failed to engage or collaborate actively with community groups with regards their CSR activity. This failure was not surprising given the "managed" nature of Russia's civil society. Thus while these findings do contribute to the extant literature on CSR in transition countries, it is clear that more research needs to be undertaken to clarify the exact nature and motivations of firms engaged in CSR in this context. This need notwithstanding, the specific findings in this article do challenge a number of assumptions within the CSR literature.

Findings in this study indicate that failure to take a broader view of what CSR is and how it is enacted, to appreciate the legal, institutional and cultural context will result in incidences of CSR being missed. For example, as a result of the lawlessness that dominated the early transition period, CSR in the Russian context appeared not only to be about going "beyond compliance" (Davis, 1973) but about being able to 
demonstrate that you were compliant with the law. Echoing Jamali \& Mirshak (2007), respondents highlighted regulatory obligations, like paying taxes and ensuring employees safety, as their "social contribution." This approach illustrates that CSR is both open to interpretation within local contexts and that CSR is not always limited to activity beyond that which is legally mandated; factors currently absent from debates on CSR theory.

Conventional thinking also assumes that CSR can and must only be "voluntary" (Carroll \& Shabana, 2010; Crouch, 2006; Dahlsrud, 2008) as it encapsulates only that activity which goes "beyond compliance" (Davies, 1973). Although in this study the type and nature of coerced CSR varied significantly, its presence illustrates that, within particular national contexts, the voluntarily nature of CSR can be and is challenged. This differences in approach to CSR again illustrates that CSR is enacted differently when cultural, legal, and institutional frameworks are applied which differ from those found within developed Western economies; yet current CSR theory fails to take account of this reality.

Also, in light of the absence of a functioning civil society and non-captured actors (Yakovlev, 2006), the findings in this study call into question the so-called prerequisites for CSR asserted by Campbell (2007) and Matten \& Moon (2008). While these scholars assert that functioning markets, an active civil society and an absence of non-captured actors are necessary for CSR to take place, there was clear evidence that international trade can drive CSR, even where these "prerequisites" were absent. CSR in the absence of these prerequisites once again challenges assumptions within the extant literature, illustrating that broadening and contextualizing CSR means adopting or assuming wider or differing interpretations of what CSR is and the conditions necessary for it to take place. 
Finally, firms also appeared to promote different motivations for engaging in CSR. Those firms motivated by commercial factors exhibited a purposeful instrumental approach (Lantos, 2001; Windsor, 2006), focused much more on the "doing well" than the "doing good" (Vogel, 1995). Conversely, those firms whose CSR was informed by the Soviet legacy exhibited a more normative motivation (Matten \& Crane, 2005; Scherer \& Palazzo, 2007). By recalling the Soviet period in explaining their motivation, describing this activity as "traditional," it was also clear that managers did not view CSR as something that was invented in the West. This view again challenges Western conventions about the antecedents of CSR. Assumptions that CSR is based on Western economic models dominate the literature, yet findings here illustrate that CSR and social interaction can emanate from other roots; in this case, central planning. Any acknowledgement that CSR is anything other than a Western construct is also, unsurprisingly, missing from the extant literature.

Thus in conclusion, the degree of contextualization within Russian CSR is significant. As stated, if a strict "beyond compliance" definition is adopted, then only $30 \%$ of firms in this study could be described as engaging in CSR. However by adopting a more nuanced and context-based approach this rises to $80 \%$ or $4 / 5^{\text {th }}$ of the 43 firms in this study. This confirms that failure to sufficiently contextualize the CSR literature will result in understanding regarding the type, nature and scope of the CSR undertaken in non-Western setting being misinterpreted or lost. It is therefore essential that more research in other non-Western settings needs to be undertaken in order to contest and/or widen the applicability of this article's conclusions.

In addition, research in other geographical areas where the extant literature is also scant, particularly in Africa, is also necessary. Such research is likely to add another dimension to how CSR is enacted and interpreted in non-Western 
environments, and where actors in other contexts view the roots of CSR. Only by broadening the scope of enquiry and theoretical development can clarification be reached on what CSR is, and why firms choose - or not - to engage in it.

Overall the findings in this article support Dobers \& Halme's (2009) call for CSR to be more contextualized, yet they raise more questions than they answer. Incorporating perspectives from transition and developing countries can and has pluralized the discussion on CSR, yet it is also reveals areas of theory may need to be revisited and re-examined. This re-examination is necessary if CSR is ever to be a concept that is not only useful at facilitating corporate social action, but really understanding what motivates firms in different locations with different cultural references to engage in CSR activity. 


\section{References}

Abdelal, R. (2010). The promise and peril of Russia's resurgent state. Harvard Business Review, 88(1/2) 125-129.

Argandoña, A., \& Hoivik, H. (2009). Corporate social responsibility: One size does not fit all: collecting evidence from Europe. Journal of Business Ethics, 89, 221-234.

Arli, D. I., \& Lasmono, H. K. (2010). Consumers' perception of corporate social responsibility in developing countries. International Journal of Consumer Studies, 34, $46-51$.

Arya, B. \& Zhang, G. (2009). Institutional reforms and investor reactions to CSR announcements: Evidence from an emerging economy. Journal of Management Studies, 46(7), 1089-1109.

Ashwin, S. (1998). Endless patience: Explaining Soviet and post-Soviet social stability. Communist and Post-Communist Studies, 31(2), 187-198.

Barkemeyer, R. (2009). Beyond compliance - below expectations? CSR in the context of international development. Business Ethics: A European Review 18(3), 273-288.

Baughn, C. C., Bodie, N. L. \& McIntosh, J. C. (2007) Corporate social responsibility and environmental responsibility in Asian countries and other geographical regions. Corporate Social Responsibility and Environmental Management, 14(4), 189-205. 
Berg, B. L. (2007). Qualitative research methods for the social sciences. London, UK: Pearson.

Blinnikov, M. S. \& Lindsey, J. R. (2010). Green youth of Russia, Kazakhstan and Ukraine: After-school naturalist programs in post-Soviet space. International Research in Geographical and Environmental Education, 19(3), 207-225.

Blasco, M. \& Zølner, M. (2010). Corporate social responsibility in Mexico and France: Exploring the role of normative institutions. Business \& Society, 49(2) 216-251.

Campbell, J. (2007). Why would corporations behave in socially responsible ways? An institutional theory of corporate social responsibility. Academy of Management 22(3), 946-967.

Carlin, W., Van Reenen, J., \& Wolfe, T. (1995). Enterprise Restructuring in Transition: the Case Study Evidence from Central and Eastern Europe, Economics of Transition, $3(4), 427-458$

Carroll, A. B. \& Shabana, K. M. (2010). The business case for corporate social responsibility: A review of concepts, research and practice. International Journal of Management Reviews 12(1), 85-105. 
Carroll, A. B. (1991). The pyramid of corporate social responsibility: Toward the moral management of organizational stakeholders. Business Horizons, 34(4), 39-48.

Chapple, W. \& Moon, J. (2005). Corporate social responsibility in Asia: A seven country study of CSR web site reporting. Business \& Society 44(4), 415-441.

Charmaz, K., \& Mitchell, R. G. (2001). Grounded theory in ethnography. In P. Atkinson, A. Coffey, S. Delamont, J. Lofland, \& L. Lofland (Eds.) Handbook of ethnography (pp. 160-174). London, UK: Sage.

Clarke, S., Fairbrother, P., Borisov, V., \& Bizyukov, P. (1994). The privatization of industrial enterprises in Russia: Four case studies. Europe-Asia Studies 46(2), 179-214

Crouch, C. (2006). Peripheral Vision: Modeling the Firms in its Market and Organizational Environments: Methodologies for Studying Corporate Social Responsibility. Organization Studies, 27(10), 1533-1551.

Dahlsrud, A. (2008). How corporate social responsibility is defined: An analysis of 37 definitions. Corporate Social Responsibility and Environmental Management 15(1), 113.

Darigan, K H \& Post, J E (2009). Corporate citizenship in china: CSR challenges in the harmonious society. Journal of Corporate Citizenship, 35, 39-53. 
Davis, K. (1973). The case for and against business assumption of social responsibilities. Academy of Management Journal, 16, 312-322.

de Vaus, D. (2001). Research design in social research. London, UK: Sage Publications.

Devinney, T. M. (2009). Is the socially responsible corporation a myth? The good, the bad and the ugly of corporate social responsibility. Academy of Management Perspectives 23(2), 44-56.

Dobers, P. (2009). Corporate social responsibility: Management and methods. Corporate Social Responsibility and Environmental Management, 16(4), 185-191.

Dobers, P., \& Halme, M. (2009). Corporate social responsibility and developing countries. Corporate Social Responsibility and Environmental Management 16(2), 237259.

Earle, J. S., Spice, A., \& Peter, K. S. (2010). The normalization of deviant organizational practices: wage arrears in Russia 1991-1998. Academy of Management Journal 53(2), 218-237.

Eisenhardt, K. (1989). Building theory from case study research. Academy of Management Review, 14(4), 532-550. 
Frye, T. (2002). Capture or exchange? Business lobbying in Russia. Europe-Asia Studies 54(7), 1017-1036.

Gel' man, V. (2003). Post-Soviet transitions and democratization: Towards theorybuilding. Democratization, 10(2), 87-104.

Gustafson, T. (2000). Capitalism Russian-style. New York, NY: Cambridge University Press.

Halme, M., Roome, N., \& Dobers, P. (2009). Corporate responsibility: Reflections on contexts and consequences. Scandinavian Journal of Management 25(1), 1-9.

Hanson, P. \& Teague, E. (2005). Big business and the state in Russia. Europe-Asia Studies, 57(5), 657-680.

Hanson, P. (1997). Samara: A preliminary profile of a Russian region and its adaptation to the market. Europe-Asia Studies, 49(3), 407-429.

Hellman, J. (1998). Winners take all: The pitfalls of partial reforms. World Politics, 50(2), 203-234.

Holmes, L. (1997). Corruption and the crisis of the post-communist state. Crime, Law \& Social Change, 27, 1-23. 
Holmes, L. (2008). Corruption and organized crime in Putin's Russia. Europe-Asia Studies 60(6), 1011-1031.

Huberman A. M., \& Miles, M. B. (1994). Data management and analysis methods. In N. K. Denzin \& Y. S. Lincoln (Eds.), Handbook of qualitative research (pp. 428-445). Thousand Oaks, CA: Sage Publications.

Jamali, D., \& Mirshak, R. (2007). Corporate social responsibility (CSR): Theory and practice in a developing country context. Journal of Business Ethics, 72(3), 243-262.

Javeline, D., \& Lindemann-Komarova, S. (2010). A balanced assessment of Russian civil society. Journal of International Affairs, 63(2), 171-188.

Kamhi, A. (2006). The Russian NGO law: Potential conflicts with international, national, and foreign legislation. International Journal of Not-for-Profit Law, 9(1), 3457.

Koleva, P., Rodet-Kroichvili, N., David, P., \& Marasova, J. (2010). Is corporate social responsibility the privilege of developed market economies? Some evidence from central and eastern Europe. The International Journal of Human Resource Management, 21(2), $274-293$.

Kornai J. (1992). The socialist system. The political economy of communism. Princeton, NJ: Princeton University Press 
Kuznetsov, A., \& Kuznetsova, O. (2003). Institutions, business and the state in Russia. Europe-Asia Studies, 55(6), 907-922.

Kuznetsov, A., Kuznetsova, O., Warren, R. (2009). CSR and the legitimacy in transition economies: the case of Russia. Scandinavia Journal of Management 25, 37-45.

Lane, D. (2000). What kind of capitalism for Russia? A comparative analysis. Communist and Post-Communist Studies, 33, 485-504.

Lantos, G. P. (2001). The boundaries of strategic corporate social responsibility. Journal of Consumer Marketing 18(7), 595-630.

Li, W. \& Zhang, R. (2010). Corporate social responsibility, ownership structure and political interference: evidence from China. Journal of Business Ethics, 96(4) 631-645.

Lin, L-W. (2010). Corporate social responsibility in China: window dressing or structural change? Berkeley Journal of International Law, 28(1), 64-100.

McWilliams, A. \& Siegel, D. (2001). 'Corporate social responsibility: A theory of the firm perspective', Academy of Management Review vol 26, 1, 117-127

Mandel, D. (2005). Managed democracy: capital and state in Russia'. Debatte: Journal of Contemporary Central and Eastern Europe, 13(2), 117 - 136.

Mason, J. (1996) Qualitative Research. London: Sage. 
Mansvelt, J. (2005). Geographies of consumption, London, UK: Sage.

Matten, D. \& Crane, A. (2005). Corporate citizenship: Toward an extended theoretical conceptualization. Academy of Management Review 30(1), 166-179.

Matten, D. \& Moon, J. (2008). Implicit and explicit CSR: A conceptual framework for a comparative understanding of corporate social responsibility. Academy of Management Review, 33(2), 404-424.

McCarthy, D. J. \& Puffer, S. M. (2008). Corporate governance as a foundation for corporate social responsibility in transitioning economies: The Russian experience. Thunderbird International Business Review 50(4), 231-243.

Miles, M. B., \& Huberman, A. M. (1999). Qualitative data analysis (2nd ed.). London: Sage.

Mitchell, R. K., Agle, B. R., \& Wood, D. J. (1997). Towards a theory of stakeholder identification and salience: defining the principle of who or what really counts. Academy of Management Review, 22(4), 853-886.

Muller, A. \& Kolk, A. (2010). Extrinsic and intrinsic drivers of corporate social performance: evidence from foreign and domestic firms in Mexico. Journal of Management Studies, 47, 1-26. 
Preuss, L. \& Barkermayer, R. (2011). CSR priorities of emerging economy firms: is Russia a different shape of BRIC? Corporate Governance, 11(4), 371-385

Puffer, S. M. \& McCarthy, D. J. (2007). Can Russia's state-managed, network capitalism be competitive? Institutional pull versus institutional push. Journal of World Business, 42(1), 1-13.

Puffer, S. M. \& McCarthy, D. J. (2011). Two decades of Russian business and management research: an institutional theory perspective. Academy of Management Perspectives, 25(2), 21-36.

Ray, S. (2008). A case study of shell at Sakhalin: having a whale of a time? Corporate Social Responsibility and Environmental Management 15(2), 173-185.

Robertson, D. C. (2009). Corporate social responsibility and different stages of economic development: Singapore, Turkey and Ethiopia. Journal of Business Ethics 88, $617-633$

Rosefielde, S. \& Hlouskova, R. (2007). Why Russia is not a democracy. Comparative Strategy 26(3), 215-230.

Rutland P (ed.) (2001). 'Business and the state in contemporary Russia'. Boulder, Westview Press. 
Scherer, A. G. \& Palazzo, G. (2007). Toward a political conception of corporate responsibility: business and society seen from a Habermasian perspective. Academy of Management Review 32(4), 1096-1120.

Sil, R. \& Chen, C. (2004). State legitimacy and the (in)significance of democracy in Post-Communist Russia. Europe-Asia Studies, 56(3), 347-368.

Silverman, D. (1993). Interpreting qualitative data: Methods for analyzing talk, text and interaction. London, Sage.

Solnick, S. L. (1999). Russia's “Transition”: Is democracy delayed democracy denied? Social Research, 66(3), 789-824.

Stoian, R. \& Zaharia, P. (2009). Corporate social responsibility in Romania: Trends, drivers and opportunities. International Journal of Economics and Business Research, $1(4), 422-437$.

Stoner-Weiss K. (1999). Central weakness and provincial autonomy: Observations on the devolution process in Russia. Post-Soviet Affairs, 15(1), 87-106.

Vahtra, P., Liuhto, K., \& Lorentz, H. (2007). Privatization or Re-nationalization in Russia? Strengthening strategic government policies within the economy. Journal of East European Management Studies, 273-296. 
Visser, W. (2005). Corporate citizenship in South Africa: A review of progress since democracy. Journal of Corporate Citizenship, 18, 29-38.

Vogel, D. (2005). The market for virtue: The potential and limits of corporate social responsibility. Washington, DC: Brookings Institution Press.

Waddock, S. A. \& Graves S. B. (1997), 'The Corporate Social Performance Financial Performance Link', Strategic Management Journal, 18(4), 303-319

Wegren, S. K. \& Konitzer, A. (2007). Prospects for a managed democracy in Russia. Europe-Asia Studies 59(6), 1025-1047.

Wildowicz-Giegiel, A. (2010). The implementation of the concept of corporate social responsibility in Polish enterprises. Olsztyn Economic Journal, 5(1), 145-158.

Windsor, D. (2006). Corporate social responsibility: three key approaches. Journal of Management Studies 43(1), 93-114.

Wood, D. J. \& Logsdon, J. M. (2001). 'Theorizing business citizenship', in Andriof J \& McIntosh M (eds.) Perspectives on Corporate Citizenship, Sheffield, Greenleaf, pp 83103.

Woodruff D. (1999). 'Money Unmade: Barter and the Fate of Russian Capitalism. Ithaca, NY: Cornell University Press 
Xu, S. \& Yang, R. (2010). Indigenous characteristics of Chinese corporate social responsibility conceptual paradigm. Journal of Business Ethics, 93, 321-333.

Yakovlev, A. (2001). Black cash, tax evasion in Russia: incentives and consequences at firm level. Europe-Asia Studies, 53(1), 33-55.

Yakovlev, A. (2006). The evolution of business-state interaction' in Russia: From state capture to business capture? Europe-Asia Studies 58(7), 1033-1056.

Zueva-Owens, A., \& Fairbrass, J. (2010). Relational governance and the development of CSR in Russia: What role for government and civil society as drivers of practice? Bradford University Management School, Working Paper No 10/01.

Jo Crotty Ph.D. is Professor of Strategy and Corporate Social Responsibility at Salford Business School, Manchester, UK. Her research interests are in the areas of statesociety-business relations, CSR and corporate greening in transition countries, predominantly Russian and China. She has published in Environment and Planning C, Non-profit and Voluntary Sector Quarterly and Organization Studies. 


\section{Appendix 1}

List of Firms (under pseudonym) in Study and Geographical Location

\begin{tabular}{|c|c|c|c|}
\hline & Firm & Location & CSR Type* $^{*}$ \\
\hline 1 & Aluminum 1 & Nevinnomyssk, Stavropol Krai & $\mathrm{MD} ; \mathrm{SP}$ \\
\hline 2 & Aluminum 2 & Nevinnomyssk, Stavropol Krai & $\mathrm{MD}$ \\
\hline 3 & Aluminum 3 & Samara, Samara Oblast' & $\mathrm{SP}$ \\
\hline 4 & Aluminum 4 & Samara, Samara Oblast' & MD; SP \\
\hline 5 & Asbestos 1 & Volzhskii, Volgograd Oblast' & $\mathrm{TL}$ \\
\hline 6 & Automobile 1 & Tol'yatti, Samara Oblast' & TL; SP \\
\hline 7 & Automobile 2 & Tol'yatti, Samara Oblast' & TL \\
\hline 8 & Automobile 3 & Tol'yatti, Samara Oblast' & $\mathrm{MD} ; \mathrm{SP}$ \\
\hline 9 & Automobile 4 & Tol'yatti, Samara Oblast' & $\mathrm{N}$ \\
\hline 10 & Ceramics 1 & Samara, Samara Oblast' & $\mathrm{C}$ \\
\hline 11 & Chemical 1 & Volzhskii, Volgograd Oblast' & SP; TL \\
\hline 12 & Chemical 2 & Volzhskii, Volgograd Oblast' & $\mathrm{C}$ \\
\hline 13 & Chemical 3 & Volgograd, Volgograd Oblast' & $\mathrm{MD} ; \mathrm{C}$ \\
\hline 14 & Chemical 4 & Volgograd, Volgograd Oblast' & $\mathrm{MD} ; \mathrm{TL}$ \\
\hline 15 & Chemical 5 & Nevinnomyssk, Stavropol Krai & SP \\
\hline 16 & Chemical 6 & Nevinnomyssk, Stavropol Krai & MD \\
\hline 17 & Chemical 7 & Samara, Samara Oblast' & MD \\
\hline 18 & Chemical 8 & Novokuibyshevsk, Samara Oblast' & SP; TL \\
\hline 19 & Construction 1 & Stavropol, Stavropol Krai & TL \\
\hline 20 & Cosmetics 1 & Novokuibyshevsk, Samara Oblast' & MD \\
\hline 21 & Cosmetics 2 & Nevinnomyssk, Stavropol Krai & $\mathrm{MD} ; \mathrm{C}$ \\
\hline 22 & Engineering 1 & Novokuibyshevsk, Samara Oblast' & $\mathrm{N}$ \\
\hline 23 & Engineering 2 & Svetlograd, Stavropol Krai & $\mathrm{N}$ \\
\hline 24 & Food Processing 1 & Stavropol, Stavropol Krai & $\mathrm{TL}$ \\
\hline 25 & Food Processing 2 & Svetlograd, Stavropol Krai & $\mathrm{TL}$ \\
\hline 26 & Lime Processing 1 & Zhigulevsk, Samara Oblast' & TL \\
\hline 27 & Metal Working 1 & Volzhskii, Volgograd Oblast' & MD; SP; C \\
\hline 28 & Metal Working 2 & Svetlograd, Stavropol Krai & SP \\
\hline 29 & Natural Resources 1 & Volgograd, Volgograd Oblast' & $\mathrm{SP} ; \mathrm{C}$ \\
\hline 30 & Natural Resources 2 & Volgograd, Volgograd Oblast' & SP \\
\hline 31 & Natural Resources 3 & Budennovsk, Stavropol Krai & MD \\
\hline 32 & Natural Resources 4 & Novokuibyshevsk, Samara Oblast' & SP \\
\hline 33 & Natural Resources 5 & Novokuibyshevsk, Samara Oblast' & $\mathrm{MD} ; \mathrm{SP}$ \\
\hline 34 & Natural Resources 6 & Samara, Samara Oblast' & $\mathrm{MD} ; \mathrm{SP}$ \\
\hline 35 & Natural Resources 7 & Samara, Samara Oblast' & $\mathrm{MD} ; \mathrm{SP}$ \\
\hline 36 & Natural Resources 8 & Novokuibyshevsk, Samara Oblast' & SP \\
\hline 37 & Pipe Factory 1 & Volgograd, Volgograd Oblast' & $\mathrm{N}$ \\
\hline 38 & Plastics 1 & Syzran, Samara Oblast' & $\mathrm{N}$ \\
\hline 39 & Quarry 1 & Zhiguliovsk, Samara Oblast' & $\mathrm{C}$ \\
\hline 40 & Ship Builders 1 & Volgograd, Volgograd Oblast' & $\mathrm{N}$ \\
\hline 41 & Tractor Factory 1 & Volgograd, Volgograd Oblast' & $\mathrm{N}$ \\
\hline 42 & Waste Processing 1 & Samara, Samara Oblast' & $\mathrm{TL}$ \\
\hline 43 & Waste Processing 2 & Tol'yatti, Samara Oblast' & $\mathrm{N}$ \\
\hline
\end{tabular}

$* \mathrm{MD}=$ Market Driven CSR; SP = Soviet Legacy and Philanthropy; TL = Transition Legacy; $\mathrm{C}=$ Coerced CSR; $\mathrm{N}=$ No CSR 
${ }^{1}$ An Oblast' is an administrative region equivalent to a State of County. It has its own elected legislature and its own budget. A Krai is similar to an Oblast' but significantly larger in geographical size, usually with greater ethnic diversity. The Governor of each Oblast' and/or Krai is appointed by the President of the Russian Federation. 